\title{
Danışanların Psikolojik Danışma Sürecinde Algıladıkları Yaşantı ve Davranış Değişimi Düzeylerinin Bazı Değişkenlere Göre Yordanması
}

\section{The Prediction of Perceived Experience and Behavior Change Levels of Clients in Counseling Process}

\author{
Aslıhan GÜMÜŞKAŞıK ' Uzman Psikolojik Danışman, Çandarlı Mehmet Dilsiz Ortaokulu, İzmir/ TÜRKiYE, aslihan- \\ sen@windowslive.com
}

Serkan DENIZLi ${ }^{D}$, Dr. Öğr. Üyesi, Ege Üniversitesi Eğitim Fakültesi, RPD Anabilim Dalı, İzmir/ TÜRKiYE, serkan.denizli@ege.edu.tr

Gümüşkaşık, A. ve Denizli, S. (2021). Danışanların Psikolojik Danışma Sürecinde Algıladıkları Yaşantı ve Davranış Değişimi Düzeylerinin Bazı Değişkenlere Göre Yordanması.Batı Anadolu Eğitim Bilimleri Dergisi, 12 (1), 158-176.

Öz. Bu araştırmanın amacı, psikolojik danışma süreci sonunda danışanların göstermiş oldukları yaşantı ve davranış değişim düzeyinin danışanların algıladıkları sosyal destek düzeyi, cinsiyeti, katılmış oldukları oturum sayısı ve problem çözme tarzlarına göre incelenmesidir. Araştırma betimsel bir alan araştırmasıdır. Araştırmanın örneklemi orta ve büyük ölçekteki 12 devlet üniversitesinde RPD lisans programında öğrenim gören psikolojik danışman adaylarının psikolojik yardım sunduğu 200 danışandan oluşmuştur. Araştırmada veri toplama aracı olarak Çok Boyutlu Algılanan Sosyal Destek Ölçeği (ÇBASDÖ), Problem Çözme Envanteri (PÇE), Yaşantı ve Davranışlarda Değişim Ölçeği (YADA) ve araştırmacı tarafından hazırlanan Bilgilendirilmiş Onay Formu ile bilgilendirme mektupları kullanılmıştır. Danışanların yaşantı ve davranışlardaki değişim düzeylerinin danışanların katılmış oldukları oturum sayısı, cinsiyeti, algılanan sosyal destek ve problem çözme becerisi değişkenlerine göre yordanıp yordanmadığını incelemek için çoklu doğrusal hiyerarşik regresyon analizi yapıımıştır. Araştırmanın bulgularına bakıldığında, danışanların cinsiyetinin, algıladıkları sosyal destek düzeylerinin ve katılmış oldukları oturum sayısının psikolojik danışma sürecinde algıladıkları yaşantı ve davranış değişim düzeyini yordamada anlamsız bulunduğu görülmüştür. Danışanların aceleci problem çözme, kaçıngan problem çözme, değerlendirici problem çözme, kendine güvenli problem çözme, planlı problem çözme tarzı puanları, yaşantı ve davranışlarda değişim düzeyi puanlarını yordamada istatistiksel olarak anlamsız bulunmuştur. Bu problem çözme tarzları ile danışanların algıladıkları yaşantı ve davranış değişim düzeyi arasında anlamlı bir ilişki bulunamamıştır. Sadece danışanların düşünen tarz problem becerisi ile algıladıkları yaşantı ve davranış değişimi düzeyi arasında anlamlı ve olumsuz bir ilişki olduğu ortaya konmuştur.

Anahtar Kelimeler: Psikolojik danışma sonucu, Problem çözme tarzı, Algılanan sosyal destek, Psikolojik danışmada danışan değişkenleri.

\begin{abstract}
Purpose of this study was to examine client's experience and behavior change levels according to perceived social support, gender, number of the sessions they attended and problem solving styles. This study is a descriptive field research. The sample of this study consisted of 200 clients who had counseling from counselor trainees, attending Guidance and Counseling Undergratuade Program at different 12 state universities in 20112012 and 2012-2013 academic years. Multidimensional Scale of Perceived Social Support, Problem Solving Inventory, The Change in Experiences and Behaviors Scale were used in order to collecting data. Also informed consent form and inform letters developed by the researcher were used to inform clients and counselor trainees. Multiple linear hierarchical regression was used to analyze whether clients' experience and behavior change
\end{abstract}


levels predicted by clients' attended session numbers, gender, perceived social support and problem solving styles. The result of this study indicated that clients' experience and behavior change levels were not predicted by clients' gender, perceived social support, problem solving styles and session number. Quick-tempered problem solving, avoidant problem solving, evaluator problem solving, self-confident problem solving, planned problem solving did not predict clients' experience and behavior change level. The relationship between these problem solving styles with experience and behavior change level was also found insignificant. The only problem solving style is thinking style which has a relationship in a negative and significant way with clients' experience and behavior change levels.

Keywords: Counseling outcome, Problem solving style, Perceived social support, Client variables in counseling. 


\section{Extended Abstract}

Introduction. Counseling process research examines the events that occur during the counseling. Variables such as therapist behavior, client behavior and interaction between therapist-client can be given as examples (Hill, 1982, 1990; cited in Heppner, Kivlighan and Wampold, 1999). Counseling outcome research, on the other hand, generally examines the existence and extent of immediate or long-term changes arising from counseling processes (Heppner et al., 1999). The main purpose of counseling process and outcome studies is to reveal the factors that lead the client to show positive changes in the counseling process. (Lambert, Bergin and Garfield, 2004).

It is suggested that the biggest proportion in the variance explained regarding the counseling outcome belongs to the personality traits of the client (Bergin and Lambert, 1979; Frank, 1979; cited in Clarkin and Levy, 2004). Up to $40 \%$ of client change can be associated with client variables and factors that are not directly part of the therapy process (Lambert, 1992; Clarkin and Levy, 2004). Clarkin and Levy (2004) emphasized that client variables are both mediator and moderator variables in terms of counseling process and outcome.

The variables belonging to the client may be related to external factors (social support) or internal factors (intelligence). Internal factors can be specified as the client's motivation, ego strength, and psychological readiness. These elements can be improved or not, they are innate or can be gained later. External factors, on the other hand, are the social support network, professional status, financial status or events that occur during the counseling process (Gordon, 2012). When we look at the quality of these variables, they can be either constant (ethnicity, gender) or relatively constant (personality traits) or highly variable (motivation for change). The variables belonging to the client may be psychological such as personality traits or related to biological structure such as REM sleep characteristics (Clarkin and Levy, 2004). Among the external factors of the client, social support is the most researched one.

Purpose of this study was to investigate client's experience and behavior change levels after they attended counseling. When counseling process and outcome studies are reviewed within the relevant literature, it is possible to claim that the variables regarding client characteristics were quite ignored. In this study, it was aimed to reveal the relationships between the level of experience and behavior change that clients perceived at the end of the counseling process, the gender of the clients, perceived social support, problem solving skills, and the number of sessions they attended.

Method. Purpose of this study was to examine client's experience and behavior change levels according to perceived social support, gender, number of the sessions they attended and problem solving styles. This study is a descriptive field research. The sample of this study consisted of 200 clients who had counseling from counselor trainees, attending Guidance and Counseling Undergraduate Program at different 12 state universities. Multidimensional Scale of Perceived Social Support, Problem Solving Inventory, The Change in Experiences and Behaviors Scale were used in order to collecting data. Also informed consent of the clients and counselor trainees were assured by the researcher with an informed consent form. Multiple linear hierarchical regression was used to analyze whether clients' experience and behavior change levels predicted by clients' attended session numbers, gender, perceived social support and problem solving styles.

Results. The result of this study indicated that clients' experience and behavior change levels were not predicted by clients' gender, perceived social support and session number. Quick-tempered problem solving, avoidant problem solving, evaluator problem solving, self-confident problem solving, planned problem solving did not predict clients' experience and behavior change level. The only significant predictor of the clients' experience and behavior change levels was the problem solving style was the "thinking style" which presented a negative and significant relationship with the clients' experience and behavior change level. 
Discussion and Conclusion. In this study, the number of sessions attended by the clients was not a significant predictor of the client's level of experience and behavior change they perceived after the counseling process. In this respect, considering the small number of sessions reached, we can claim that it was an expected result that no change was observed. Another finding of the study indicated that being a male or female as clients did not change the level of experience and behavior change perceived by the clients. Counseling outcome studies related with the gender effect are very limited. When the existing studies are reviewed, mostly inconsistent findings were revealed.

The thinking problem-solving styles of the clients predicted the scores of the level of change in experiences and behaviors as a result of counseling. We can conclude that due to their thinking problem solving style, clients' focusing on their problems and its dimensions intensely may increase their stress levels. Level of social support perceived by the clients was not found as a significant predictor of the level of experience and behavior change of the clients as they perceived during the counseling process. This finding was consistent with a few similar findings whereas it was contradicting the findings between social support and positive mental health. From this point of view, this finding should be con carefully and interpreted with the findings of future research on university students receiving psychological assistance and the role of their social support in this process. 


\section{Giriş}

Pek çok insan yaşamındaki zorluklara ya da değişikliklere kendi çabası, arkadaşları, ailesi ya da dini inançları sayesinde uyum sağlayabilmektedir. Bununla birlikte, tüm sosyal destek sistemlerine rağmen, bazen profesyonel bir yardımcının bu zorluklar ile baş etme konusunda desteğine ihtiyaç duyabilir (Hackney ve Cormier, 2005). Psikolojik danışma, terapötik bir ortamda, değişim için risk alan iki kişi arasında yaşanan bir süreçtir. Diğer bir ifade ile, kişinin yaşadığı değişimler ve zorluklar karşısında psikolojik danışman ve danışanın birlikte çözüm üretmelerini içeren, iş birliği içinde yürütülen bir süreçtir (Corey, 2008). Psikolojik danışma danışanın yaşamında değişim yaratma, yaşamdaki olası riskleri önleme ve danışan yaşamını zenginleştirerek daha işlevsel hale getirmede bir araç olarak değerlendirilebilir. Aşırı stres, tatminsizlik ya da mutsuzluk gibi duygular yaşamın normal seyrinden çıkmasına neden olabilir. Psikolojik danışma sürecinin önleme boyutu ile kişinin olası gerginliklere ve risklere hazırlıkı olması sağlanabilir, böylelikle danışan kendi kendine yardım etme becerisi ve değişen yaşam koşullarına uyum sağlama becerisini geliştirebilir. Zenginleştirme boyutunda ise kişi yaşamındaki olası fırsatlara dair yeni bir kavrayış ve algı geliştirebilir (Hackney ve Cormier, 2005).

Bireylerin yaşamları boyunca karşılaştıkları güçlükler ile baş edebilmesi bazı dönemlerde ayrıca önem kazanmaktadır. Üniversite yaşamı da bu dönemlerden biridir. Üniversiteye başlayan öğrenciler hem akademik hem de sosyal anlamda yepyeni bir çevre ile tanışır. Bu çevre ile tanışma ve sonrasındaki adaptasyon süreci onlara pek çok değişim, gelişim ve yeni yaşantı imkânları sunarken diğer yandan da akademik, kişisel ve sosyal anlamda bazı zorluklar ile baş etme zorunluluğu getirmektedir. Bu zorlukların başlıca sebepleri gençlerin alışmış oldukları sosyal çevreden ayrılmış olmalarıdır (Sürücü ve Bacanlı, 2010).

Ülkemizde üniversite öğrencilerinin yaşadıkları problemleri inceleyen araştırmalara bakıldığında bu problemlerin uyum problemleri, akademik problemler, karşı cinsle ilişki ve iletişim problemleri, iş bulma ve gelecek kaygısı problemleri, problemler, aile problemleri, stres, kararsızlık, kaygı, depresyon gibi psikolojik sağlıkla ilgili problemler olarak sıralanabilir (Demir ve Koydemir, 2005; Erkan, Özbay, Cihangir-Çankaya ve Terzi, 2012; Güneri-Yerin, Aydın ve Skovholt, 2003; Özgüven, 1992, Akt. Topkaya ve Meydan, 2013). Yapılan araştırmalardan da anlaşılacağı gibi üniversite öğrencilerinin bu dönemde psikolojik yardım almalarını gerektiren birçok kişisel-sosyal, eğitsel ve mesleki sorunla karşı karşıya kaldıkları söylenebilir (Topkaya ve Meydan, 2013). Üniversite yıllarında öğrencilerin psikolojik yardım almaları bu sorunlar ile başa çıkmak adına önem taşımaktadır.

Psikolojik danışma, danışanların ilerleme göstermesine yardımcı olacak bir potansiyele sahiptir. Psikolojik danışma sürecini oluşturan bileşenleri anlamak önemlidir. Psikolojik danışmayı etkileyen faktörler danışan ve psikolojik danışman arasındaki ilk etkileşimden itibaren başlar (Sexton,1993). Hem danışan hem de psikolojik danışman sürece, psikolojik danışmanın sonucunu etkileyebilecek belirli özellikler ile girer. 25 yılın klinik araştırmaları gözden geçirildiğinde, Frank (1974) uzun süreli psikolojik danışma ilerlemelerinin en önemli belirleyicileri arasında danışanla ilgili faktörler veya özelliklerin yer aldığını ileri sürmektedir (Sexton, 1993). Psikolojik danışma uygulama ve araştırmalarında danışan özelliklerine $90^{\prime}$ ı yıllara kadar çok fazla odaklanılmamıştır. Bununla birlikte psikolojik danışmanlar danışanın kişiliği, davranışı ve motivasyonunu psikolojik danışma başarısında kritik faktörler olarak değerlendirmektedir (Nugent, 1990). Rogers (1942) ilk kitabında danışan özelliklerinin verimli bir çalışma ilişkisine katkıda bulunduğunu açıklamaktadır. Psikolojik danışmadan etkili yararlanan danışanların problemlerini açıklamaya gönüllü, orta düzeyde baş etme ve yeterince sözel ifade etme becerisine sahip ve orta düzeyde bağımsız bireyler olduklarını belirtmiştir (Akt. Nugent, 1990). Ayrıca literatürde incelenen diğer danışan özelliklerine sosyal sınıf, tanı (problem türü), yaş, cinsiyet ve zekâ (Garfield, 1986); danışan beklentileri (Brammer ve Shostrom, 1982) gibi örnekler verilebilir (Akt. Nugent, 1990). Heilbrun (1982, Akt. Nugent, 1990) danışanların varolan problemin neden ortaya çıktı̆ı̆ıı keşfetmeye gönüllü olup, problemleri için sorumluluk aldığında ve bu problemleri ele alma 
hatalarını düzeltmek için yeni yollar aradığında psikolojik danışma başarısına katkıda bulunduklarını belirtmektedir. Brown ve Srebalus (1988) ise istenen danışan özelliklerinin zekâ, esneklik, güvenilirlik, problemleri ve eylemleri için sorumluluk alabilmeyi içerdiğini söylemektedir (Akt. Nugent, 1990).

Garfield (1986) çalışmasında danışan özellikleri ve terapi sonuçları arasındaki ilişki üzerine yapılan araştırmaları şu şekilde özetlemiştir: "Psikoterapi sonuçları ile ne tür danışan özelliklerinin ilişkili olduğu sorusunu cevaplamak varolan araştırma verileri ile oldukça zordur. Her ne kadar sosyal sınıf, cinsiyet, yaş gibi değişkenlerin psikoterapi sonuçlarının yordayıcısı olmadığını belirtsek de kişisel özelliklere dayalı kesin ifadeler kullanmak daha zordur" (Akt. Nugent, 1990). Bu nedenle danışan özellikleri ile ilgili daha kapsamlı araştırmalar yapılmasını önermektedir (Nugent, 1990).

Psikoterapi süreçleri ve etkilerine dair araştırmalar bilinmezliğini korumuş ve bu araştırmalar psikoterapinin kuram ve uygulamaları üzerindeki vurgularını çok az oranda ortaya koymuştur. Ancak psikoterapi araştırmaları, terapistlerin kuram odaklı çalışmaları ve uygulamaları için gerekli ve gelişen bir girişimdir (Lambert vd., 2004). Ülkemizde psikolojik danışma süreç ve sonuç araştırmalarının durumu incelendiğinde, bu konudaki araştırmaların oldukça az sayıda olduğu görülmektedir. Son yıllarda gerçekleştirilen araştırmalara bakıldığında, psikolojik danışma sürecinin psikolojik danışman davranışları ve psikolojik danışma becerileri açısından incelenmeye başlandığı görülmektedir (örn. Aladağ ve Bektaş, 2007; Aladağ ve Bektaş, 2009; Denizli, 2010; Meydan, 2010; Yaka, 2005). Psikolojik danışma sürecinde temel öğelerden biri olan danışanlara yer veren araştırmalar da az sayıda olmakla birlikte literatürde mevcuttur (örn. Denizli, 2010; İ̧legen, 2011; Sanberk, 2010).

Çoğu meslek başarı göstergelerine sahiptir. İ̧ adamları için belirli alım-satım işlemleri, futbol takımları için galibiyetler, avukatlar için kazandıkları davalar, mühendisler ve mimarlar için yaptıkları binalar, çiftçiler için yetiştirdikleri ürünler, doktorlar için kurtardıkları hayatlar, din adamları için dinsel törenler bunlar arasında sayılabilir. Psikolojik danışma ortaya koyduğu ürünü somut olarak görünmeyen neredeyse tek alandır. İnsanların psikolojik danışma alanında başarı kanıtı görmeye dair giderek artan bir talebi vardır ve bu oldukça doğaldır (Leibert, 2006).

Psikolojik danışma süreci sonunda danışanda gerçekleşen değişim ya da gelişimin somut bir şekilde ortaya konabilmesi için danışanların bu sürece ilişkin geribildirimleri önem taşımaktadır. Danışanların sahip oldukları hangi özelliklerin, psikolojik danışma süreci sonunda danışanda ne yönde bir değişim ve gelişim sağladığı araştırımaya açık bir alandır. Psikolojik danışma sürecinde danışan faktörlerinin ülkemizde yeni bir araştırma sahası olduğu görülmüştür. Bu nedenle bu araştırmada danışanların cinsiyeti, sahip oldukları problem çözme tarzları ve algıladıkları sosyal destek düzeyinin, psikolojik danışma süreci sonunda danışanın algıladığı yaşantı ve davranış değişimi düzeyini yordama gücünün araştırılması planlanmıştır. Danışanların katılmış olduğu oturum sayısı, danışanın gerçekleştirdiği değişim düzeyini ortaya koymada anlamlı bir değişken olarak bulunmuştur (Howard, Kopta, Krause ve Orlinsky, 1986, Akt. Lambert, 2006). Danışanların gerçekleştirdiği değişim düzeyini daha sağlıklı inceleyebilmek için, danışanların katılmış olduğu oturum sayısı da araştırmanın bağımsız değişkenlerinden biri olarak ele alınmıştır.

İlgili literatürde psikolojik danışma sonuç araştırmaları incelendiğinde danışan özelliklerinin oldukça göz ardı edildiği görülmektedir. Bu araştırmada, danışanların psikolojik danışma süreci sonunda algıladıkları yaşantı ve davranış değişimi düzeyinin, danışanların cinsiyeti, algıladığı sosyal destek, problem çözme beceri tarzı ve katılmış oldukları oturum sayısı ile ilişkisini ortaya koymak amaçlanmıştır. Psikolojik danışma sürecinde danışan tarafından algılanan değişime, danışana ait değişkenler açısından bakılan bir araştırma olması açısından önem taşımaktadır. Psikolojik danışma sürecine katılan gerçek danışanlardan veri toplanarak yapılan bir araştırmadır. iligili literatür incelendiğinde, psikolojik danışma süreci sonunda gerçekleşen değişimin ve danışan faktörlerinin bu değişime olan katkısının araştırılmaya ihtiyaç duyulan bir alan olduğu görülmektedir. Psikolojik danışma 
yardımının etkililiğini anlamaya yönelik atılacak bir adım niteliğindedir. Bu süreçte yardım alan kişi olarak tanımladığımız danışanların gözünden psikolojik danışma yardımının ne derece işlediğinin anlaşılması için yardımcı olması beklenmektedir. Psikolojik danışma sürecinde belirli danışan özelliklerinin danışanın değişimi ile ne derecede ilişkili olduğunu anlamamız için ışık tutması ve danışanın gözünden psikolojik danışma sürecinin etkililiğine geri bildirim sağlaması beklenmektedir. Danışanların algıladıkları değişim düzeyi ülkemizdeki araştırmalarda çok fazla ele alınan bir konu değildir. Bu nedenle danışan değişkenleri ile psikolojik danışma süreci sonunda danışanların algıladıkları değişimin ilişkisine bakılmasının literatüre anlamlı katkılar sağlaması düşünülmektedir.

\section{Yöntem}

\section{Araştırmanın Deseni}

Bu araştırma Rehberlik ve Psikolojik Danışmanlık lisans programı dördüncü sınıf öğrencilerinin psikolojik danışma yardımı sunduğu danışanların süreç sonunda göstermiş oldukları yaşantı ve davranış değişimlerine ilişkin bir profil çıkarılmasını amaçlamaktadır. Bununla birlikte bu araştırma psikolojik danışma süreci sonunda danışanların göstermiş oldukları yaşantı ve davranış değişim düzeyini danışanların algıladıkları sosyal destek düzeyi, cinsiyeti, katılmıs oldukları oturum sayısı ve problem çözme tarzlarına göre incelenmesini amaçlamaktadır. Bu amaçlar doğrultusunda, bu araştırma var olan bir durumun ortaya çıkarılmasını hedeflemektedir. Bu bağlamda bu araştırmanın betimleyici bir alan araştırması olduğu söylenebilir.

\section{Evren ve Örneklem}

\section{Psikolojik Danışman Adayları}

RPD lisans programı öğretim elemanları ile iletişime geçilmiş ve 12 devlet üniversitesinde psikolojik danışman adayı lisans öğrencilerinin gerçek danışanlar ile psikolojik danışma oturumları yürüttüğü görülmüştür. Bu üniversiteler orta ve büyük ölçekteki üniversiteler arasında yer almakta, ülkemizin İ̧̧ Anadolu Bölgesi ve Ege Bölgesi'nden üç, Akdeniz, Karadeniz ve Doğu Anadolu Bölgesi'nden iki üniversite olarak dağılım göstermektedir. Bu programlara devam etmekte olan tüm dördüncü sınıf öğrencilerinin (psikolojik danışman adaylarının) sayısı 880'dir (ÖSYS Yükseköğretim Programları ve Kontenjanları Kılavuzu, 2012).

Araştırma grubunda bulunacak psikolojik danışman adayları için gönüllülük esas alınmıştır. Danışanlardan veri toplama konusunda psikolojik danışman adayları aracı olacağı için katılım konusunda gönüllülüklerine önem verilmiştir.

\section{Danışanlar}

Psikolojik danışman adaylarının bireyle psikolojik danışma uygulamaları kapsamında gördüğü danışan sayısı (en az bir danışan olarak kabul edildiğinde) araştırmanın evrenini oluşturmuştur. Veri toplama işlemi tamamlandığında evrenin tamamı olan 880 psikolojik danışman adayı aracılığı ile en az 880 danışana ulaşılması beklenmiştir. Danışan profilinin çoğunlukla üniversite öğrencilerinden oluştuğu anlaşılmıştır.

Veri toplama sürecinde araştırmaya katılmak için gönüllü olmayan psikolojik danışman adayları ve danışanlar araştırmanın evreninden çıkarıımıştır. Ayrıca psikolojik danışma sürecini yarım bırakan danışanlar araştırmanın evreninin dışında tutulmuştur. Sonuç olarak 299 katıımcı araştırmanın 
ulaşılabilir örneklemi olarak kabul edilmiştir. Ulaşılabilir örneklemi oluşturan 299 katılımcıdan 214 (\%71.57) kadın, 85 (\%28.43) erkektir ve evrenin \%31.64'sini temsil etmektedir.

Araştırmaya katılan danışanlar, araştırma grubunda yer alacak psikolojik danışman adaylarından gönüllü olarak psikolojik yardım alan bireylerden oluşmuştur. Psikolojik danışman adayları aracılı̆ı ile danışanlara gönüllü katılımlarını belirtecek bir bilgilendirilmiş onay formu iletilmiştir.

\section{Veri Toplama Araçları}

Araştırma kapsamında Yaşantı ve Davranışlarda Değişim Ölçeği (YADA), Çok Boyutlu Algılanan Sosyal Destek Ölçeği (ÇBASDÖ), Problem Çözme Envanteri (PÇE) kullanılmıştır. Veri toplama araçları ile ilgili bilgiler aşağıda sunulmuştur.

\section{Yaşantı ve Davranışlarda Değişim Ölçeği}

Zielke ve Kopf-Mehnert (1978) tarafından geliştirilmiştir ve psikolojik danışma süreci sonrasında danışanlarda yaşantı ve davranış değişimi meydana gelip gelmediğini ölçmektedir. Psikolojik danışma sonrasındaki değişimin, yönü ve gücü hakkında bilgi sahibi olmak amaçlanmaktadır. Ölçekte toplam 42 madde bulunmaktadır. Maddeler 7'li bir derecelendirmeye sahiptir; ölçekten alınan toplam puan ne kadar yüksekse değişimin o kadar şiddetli-olumlu olduğunu ifade etmektedir. Bu ölçekteki 1, 4, 5, 10, 11, 13,19, 20, 21, 23, 26, 27, 28, 29, 37, 42 numaralı maddeler olumsuz maddelerdir. Olumsuz maddeler 1'den 7'ye doğru kodlanırken; olumlu maddeler 7'den 1'e doğru kodlanmaktadır (Akt. Sanberk, 2010). "Yaşantı ve Davranışlarda Değişim Ölçeği" Zielke ve KopfMehnert (2001) tarafından revize edilmiştir. Temel bileşenler analizi sonucunda 5 faktörlü bir yapı bulunmuştur. İç tutarlık katsayısı .97 olarak hesaplanmıştır. Ölçek maddelerinin toplam puan ile korelasyonları .33 ila .81 arasında olduğu kaydedilmiştir (Sanberk, 2010). Sanberk (2010) tarafından ölçeğin uyarlama çalışması yapılmıştır. Ölçeğin Cronbach Alfa katsayısı .96' tır. Özgün çalışmada ise iç tutarlık katsayısı .97 olarak hesaplanmıştır (Sanberk, 2010). Ölçeğin test-tekrar test güvenirlik katsayısı beş hafta ara ile .72 olarak hesaplanmıştır. Özgün çalışmada ise test tekrar test ölçümleri sekiz hafta ara ile hesaplanmış ve bulunan değer .61 olarak hesaplanmıştır. Bu araştırmanın örneklemi için ise Cronbach Alfa değeri .93 olarak hesaplanmıştır.

\section{Çok Boyutlu Algılanan Sosyal Destek Ölçeği}

Çok Boyutlu Algılanan Sosyal Destek Ölçeği (Multidimensional Scale of Perceived Social Support MSPSS), Zimet ve Dahlem (1988) tarafından "aile", "arkadaş" ve "diğer önemli kişi" ya da "özel bir kişi" gibi üç kaynaktan (aile 3, 4,8, 11; arkadaş 6, 7, 9, 12; özel bir kişi 1, 2, 5, 10) sağlanan desteğin yeterliliğini değerlendirmek üzere geliştirilen 12 maddelik bir ölçektir. Her biri 4'er maddeyi içeren üç alt ölçekten oluşan ÇBASD ölçeği 1'den 7'ye kadar puanlanan Likert tipi bir ölçektir (Çakır ve Palabıyıkoğlu, 1993). Her alt ölçekteki dört maddenin puanlarının toplanması ile alt ölçek puanı elde edilir ve bütün alt ölçek puanlarının toplanması ile de ölçeğin toplam puanı elde edilmiş olur. Elde edilen puanın yüksek olması algılanan sosyal desteğin yüksek olduğunu ifade etmektedir (Eker, Arkar ve Yaldız, 2001).

Önerilen alt ölçekler aile, arkadaş ve özel bir insandan alınan destek olarak belirlenmiştir. Faktör analizi bu önerilen yapıyı çeşitli örneklemlerde desteklemiştir (Kazarian ve McCabe 1991, Zimet vd., 1988; 1990, Akt. Eker ve Arkar1995a). Faktör analizi çalışmalarında maddeler ilgili 3 faktör altında yer almışlar ve kümülatif olarak toplam varyansın yüzde $75^{\prime}$ ini açıklamışlardır. Geçerliği ölçmek için UCLA Yalnızlık Ölçeği, Algılanan Sosyal Destek Ölçeği, Belirti Tarama Listesi ve Beck Umutsuzluk Ölçeği kullanılmıştır. Ölçekler anlamlı korelasyon göstermiştir (Eker vd., 2001). 
Ölçeğin ve alt ölçeklerin iç tutarlılığı (Kazarian ve McCabe 1991; Zimet vd., 1988; 1990, Akt. Eker ve Arkar, 1995a) ve test-tekrar test korelasyonları (Zimet vd., 1988, Akt. Eker ve Arkar, 1995a) yeterlidir. Geçerlik açısından, ÇBASDÖ başka bir sosyal destek ölçeği ve bir benlik kavramı ölçeği ile olumlu yönde (Kazarian ve McCabe 1991) ve depresyon (Kazarian ve McCabe 1991, Zimet vd., 1988, Akt., Eker ve Arkar, 1995a) ve anksiyete (Zimet vd., 1988, Akt., Eker ve Arkar, 1995a) ölçekleriyle olumsuz yönde korelasyon göstermiştir (Çakır ve Palabıyıkoğlu, 1993). Eker ve diğerleri (2001) çalışmasında farklı örneklemler ile iç tutarlıığı ölçmek için Cronbach alfa yöntemini kullanmıştır. Değerler 0.80 ile 0.95 arasındadır ve üç örneklemde de ölçek ve alt ölçekler kabul edilebilir düzeyde iç tutarlılık göstermiştir. Bu araştırmanın örnekleminde ölçeğin Cronbach Alfa değeri .74 olarak hesaplanmıştır. Aile, arkadaş ve diğer önemli kişi alt ölçekleri için ise Cronbach Alfa değeri sırası ile .67, .62 ve .81 olarak bulunmuştur.

\section{Problem Çözme Envanteri}

Problem Çözme Envanteri, Heppner ve Peterson (1982) tarafından, bireylerin problem çözme becerisine ilişkin algısını ve problem çözme tarzını değerlendirmek için geliştirilmiş bir envanterdir (Heppner, 1988; Heppner ve Petersen, 1982, Akt. Şahin, Şahin ve Heppner, 1993). 35 maddeden oluşan ve 1-6 arasında puanlanan Likert tipi bir ölçektir. Faktör analitik çalışmaları üç faktörü açıklamıştır: Problem-çözme güveni, yaklaşma-kaçınma tarzı, kişisel kontrol (Heppner, 1988, Akt. Şahin vd., 1993). Ölçekten alınabilecek toplam puan 32-192 arasında değişmekte olup, 32-80 arası puanlar yüksek düzeyde problem çözme becerisini, 81-192 arası puanlar ise düşük düzeyde problem çözme becerisini ifade etmektedir (Sardoğan, Karahan ve Kaygusuz , 2006). Ölçeğin güvenirlik çalışmasında ölçeğin tümü için elde edilen Cronbach $\alpha$ iç tutarlılık katsayısı 0.90, alt ölçekler için elde edilen katsayılar ise 0.72 ile 0.85 arasında değişmektedir. Ölçeğin madde-toplam puan korelasyonlarının ranjı ise 0.25 ile 0.71 arasında değişmektedir. Ölçeğin alt ölçeklerinin test-tekrar test güvenirlik katsayıları $r=0.83$ ile $r=0,89$ arasında değişmektedir. Ölçeğin geçerlik çalışmasında toplam puanın ve üç alt ölçekten elde edilen puanların, öğrencilerin problem çözme becerilerinin düzeyiyle korelasyonları sırası ile 0.46 , 0.29 -, 0.44- ve -0.43 olarak hesaplanmıştır. Yapı geçerliği çalışmasında ise "problem çözme yeteneğine güven" $(5,10,11,12,19,23,24,27,33,34$ ve 35 . Maddeler, $\alpha=0.85)$, "yaklaşma kaçınma" $(1,2,4,6,7$, $8,13,15,16,17,18,20,21,28,30,31$.maddeler, $\alpha=0.84)$ ve "kişisel kontrol" $(3,14,25,26$ ve 32. Maddeler, $\alpha=0.72$ ) olmak üzere üç faktörden oluştuğu saptanmıştır. Bu üç faktör arasındaki korelasyon katsayıları ise 0.38 ile 0.49 arasında hesaplanmıştır (Savaşır ve Şahin, 1997).

Ölçeğin Türkiye uyarlaması ilk kez Taylan (1990) tarafından yapılmıştır. Taylan'ın yaptığı geçerlik çalışmasında problem çözme envanteri puanları ile kendini kabul envanteri puanları arasındaki korelasyon 0,44 sürekli kaygı envanteri puanları arasındaki korelasyon ise 0.51 olarak hesaplanmıştır. Ölçeğin güvenirlik çalışmasında; İngilizce ve Türkçe uygulamaları arasındaki güvenirlik katsayıları toplam puan için 0.86 , problem çözme güveni için 0.86 , yaklaşma-kaçınma tarzı için 0.64 ve kişisel kontrol için 0.73 olarak hesaplanmıştır. Ölçeğin toplam puanı ile alt ölçekler arasındaki korelasyon katsayıları problem çözme güveni için 0.82 , yaklaşma-kaçınma tarzı için 0.81 ve kişisel kontrol için 0.58 olarak hesaplanmıştır. Test-tekrar test yöntemiyle kararlılık katsayıları; problem çözme güveni için 0.84 , yaklaşma-kaçınma tarzı için 0.47 ve kişisel kontrol için 0.48 ve ölçeğin toplamı için 0.66 olarak hesaplanmıştır. Bu araştırmada ölçeğin uygulandığı örneklem için Cronbach Alfa değeri .78 olarak hesaplanmıştır. Alt ölçeklere ait Cronbach Alfa değerleri ise aceleci yaklaşım .67, düşünen yaklaşım .79, kaçıngan yaklaşım .63, değerlendirici yaklaşım .70, kendine güvenli yaklaşım .64 ve planlı yaklaşım .43 olarak hesaplanmıştır.

Şahin vd. (1993) ölçeğin Türkiye uyarlaması ile ilgili ikinci çalışmayı gerçekleştirmiştir. Ölçeğin güvenirlik çalışması, 244 üniversite öğrencisinden oluşan bir örneklem grubu ile yapılmıştır. Cronbach $\alpha$ güvenirlik katsayısı 0.88 olarak hesaplanmıştır. Yarıya bölme güvenirlik çalışmasında ise tek ve çift sayılı maddeler ayrılarak, yarıya bölme tekniği ile elde edilen güvenirlik katsayısı $r=0.81$ olarak 
bulunmuştur. Ölçeğin geçerlik çalışmasında; ölçüt bağıntılı geçerlik yöntemi kullanılmış ve ölçeğin toplam puanı ile Beck Depresyon Envanteri toplam puanları arasındaki korelasyon -0.33 ve STAI-T toplam puanları arasındaki korelasyon katsayısı ise -0.45 olarak hesaplanmıştır. Yapılan faktör analizi sonucunda ise ölçeğin; aceleci yaklaşım, düşünen yaklaşım, kaçıngan yaklaşım, değerlendirici yaklaşım, kendine güvenli yaklaşım ve planlı yaklaşım olmak üzere altı faktör bulunmuştur (Şahin vd., 1993).

\section{Veri Toplama Süreci}

Araştırmada kullanılan Problem Çözme Envanteri, Çok Boyutlu Algılanan Sosyal Destek Ölçeği, Yaşantı ve Davranışlarda Değişim Ölçeği araştırmacı tarafından çoğaltılarak örneklemi oluşturan 12 devlet üniversitesinin RPD Anabilim Dallarında uygulamayı yürütecek olan öğretim elemanlarına gönderilmiştir. Öğretim elemanları ve psikolojik danışman adayları için uygulama hakkında bilgilendirme mektupları da ölçekler ile birlikte gönderilmiştir. Araştırma kapsamında değerlendirilen ölçekler, 12 devlet üniversitesinde Rehberlik ve Psikolojik Danışmanlık lisans programlarında bireyle psikolojik danışma uygulaması yürüten psikolojik danışman adaylarının danışanları tarafından doldurulmuştur. Psikolojik danışman adayı ve danışanlara araştırmanın içeriği ve uygulamalar ile ilgili bilgi verilmiştir. Araştırmaya gönüllü olarak katılmak isteyen danışanların araştırmacı tarafından hazırlanan bilgilendirilmiş onay formunu doldurmaları istenmiştir. Gönüllü katılım gösteren danışanlara Yaşantı ve Davranışlarda Değişim Ölçeği, Çok Boyutlu Algılanan Sosyal Destek Ölçeği ve Problem Çözme Envanteri kapalı zarf içerisinde psikolojik danışman adayları aracılığı ile iletilmiştir. Çok Boyutlu Algılanan Sosyal Destek Ölçeği ve Problem Çözme Envanteri danışanın katılım onayı alındıktan sonra ilk oturumda uygulanmıştır. Yaşantı ve Davranışlarda Değişim Ölçeği ise psikolojik danışma sürecinde en az dört oturum gerçekleştiren danışanlara, sonlandırma oturumunun ardından uygulanmıştır. Ölçekler uygulama tamamlandığında dönem sonu itibari ile öğretim elemanları tarafından posta yolu ile araştırmacıya geri gönderilmiştir.

\section{Veri Analizi}

Danışanların algıladıkları yaşantı ve davranış değişimi düzeyininin yordayıcı değişkenlerinin değerlendirilmesi için çoklu doğrusal hiyerarşik regresyon analizi kullanılmıştır. Çoklu doğrusal hiyerarşik regresyon analizi kullanılarak yaşantı ve davranışlardaki değişim düzeyinde açıklanan toplam varyansın yorumlanması, danışanların katılmış oldukları oturum sayısı, cinsiyeti, algılanan sosyal destek ve problem çözme tarzı değişkenleri ile bağımlı değişken (yaşantı ve davranışlardaki değişim düzeyi) arasındaki ilişkinin yönü hakkında yorum yapılmıştır.

\section{Bulgular}

Danışanların katılmış oldukları oturum sayısı, cinsiyeti, problem çözme tarzı (aceleci, düşünen, kaçıngan, değerlendirici, kendine güvenli ve planlı) ve çok boyutlu algıladıkları sosyal destek düzeylerinin (aile, arkadaş, diğer önemli kişi) danışanların algıladıkları yaşantı ve davranışlarda değişim puanlarını yordama derecesini incelemek için çoklu doğrusal hiyerarşik regresyon analizi gerçekleştirilmiştir. Çoklu doğrusal hiyerarşik regresyon analizinde, problem çözme ve sosyal destek puanlarının YADA puanlarını yordama derecesi incelenirken, danışanların katılıkları oturum sayısının alınan yardımın etkililiğini belirlemedeki belirleyiciliği düşünülerek (Clement, 2008) katıldıkları oturum sayısı değişkeni birinci sırada hiyerarşik regresyon analizine sokularak kontrol edilmiştir.

Veri toplama süreci sonunda 299 danışana ulaşılmıştır. Ancak toplanan verilerde oturum sayısını belirtmemiş danışanlar veri setinden çıkarılmıştır. Ayrıca YADA (Yaşantı ve Davranışlarda Değişim Ölçeği) ile ölçülen değişimin gözlenmesi için sürece en az dört oturum devam eden 
danışanların araştırmaya dahil edilmesi kararlaştırılmıs ve devam ettiği psikolojik danışma oturumu sayısı dört oturumdan az olanlar çıkarıldıktan sonra analizlere 223 danışanın verisi üzerinden devam edilmiştir. Kayıp değer analizi yapıldığında YADA, ÇBASD (aile, arkadaş, diğer önemli kişi) ve PÇE (aceleci, düşünen, kaçıngan, değerlendirici, kendine güvenli, planlı) ölçeklerinde $\% 5$ 'ten fazla kayıp değer görülmediği için kayıp değerler yerine seri ortalamaları ataması yapılmışır. Analizlere 200 danışanın verisi üzerinden devam edilmiştir. Analize giren değişkenlere ilişkin betimleyici istatistikler Tablo 1' de ve korelasyon değerleri Tablo 2'de verilmiştir.

Tablo 1.

Danışanların bağımlı ve bağımsız değişkenlere ilişkin puanlarının ortalamaları ve standart sapmaları

\begin{tabular}{|c|c|c|c|c|c|}
\hline Değişken & $n$ & $\min$. & $\max$. & $\bar{X}$ & Ss \\
\hline Cinsiyet & 200 & - & - & .29 & .45 \\
\hline YADA & 200 & 172 & 291 & 242.87 & 27.99 \\
\hline Oturum sayısı & 200 & 4 & 13 & 5.85 & 1.83 \\
\hline SD Aile & 200 & 9 & 28 & 21.87 & 5.26 \\
\hline SD Arkadaş & 200 & 7 & 28 & 21.43 & 5.42 \\
\hline SD Diğer Kişi & 200 & 4 & 28 & 17.28 & 8.46 \\
\hline PÇ Aceleci & 200 & 15 & 47 & 30.95 & 6.65 \\
\hline PÇ Düşünen & 200 & 5 & 25 & 13.22 & 4.63 \\
\hline PÇ Kaçıngan & 200 & 4 & 23 & 13.64 & 4.95 \\
\hline PÇ Değerlendirici & 200 & 3 & 15 & 8.03 & 3.09 \\
\hline PÇ Kendine Güvenli & 200 & 8 & 28 & 17.39 & 4.72 \\
\hline PÇ Planlı & 200 & 4 & 21 & 10.76 & 3.61 \\
\hline
\end{tabular}

YADA; Yaşantı ve Davranışlarda Değişim, SD; Sosyal Destek, PÇ; Problem Çözme

Tablo 2.

YADA, oturum sayısı, cinsiyet, sosyal destek, problem çözme değişkenleri arasındaki korelasyon değerleri tablosu

\begin{tabular}{|c|c|c|c|c|c|c|c|c|c|c|c|c|}
\hline & YADA & $\begin{array}{l}\text { Oturu } \\
\text { m } \\
\text { sayısı }\end{array}$ & $\begin{array}{l}\text { Cinsiy } \\
\text { et }\end{array}$ & $\begin{array}{l}\text { Sd } \\
\text { aile }\end{array}$ & $\begin{array}{l}\text { Sd } \\
\text { ark }\end{array}$ & $\begin{array}{l}\text { Sd } \\
\text { diğ. }\end{array}$ & $\begin{array}{l}\text { Pç } \\
\text { acele. }\end{array}$ & $\begin{array}{l}\text { Pç } \\
\text { düşün. }\end{array}$ & $\begin{array}{l}\text { Pç } \\
\text { kaçın. }\end{array}$ & $\begin{array}{l}\text { Pç } \\
\text { değ. }\end{array}$ & $\begin{array}{l}\text { Pç } \\
\text { k.güve } \\
\text { nli }\end{array}$ & $\begin{array}{l}\text { Pç } \\
\text { plan } \\
\text { lı }\end{array}$ \\
\hline YADA & 1 & & & & & & & & & & & \\
\hline $\begin{array}{l}\text { Oturum } \\
\text { sayısı }\end{array}$ & .10 & 1 & & & & & & & & & & \\
\hline Cinsiyet & -.05 & -.06 & 1 & & & & & & & & & \\
\hline Sd aile & .02 & -.11 & -.06 & 1 & & & & & & & & \\
\hline \multicolumn{13}{|c|}{ Tablo 2. Devam } \\
\hline Sd ark & .07 & $-.16^{*}$ & $-.13^{*}$ & $.38^{*}$ & 1 & & & & & & & \\
\hline Sd diğer & .02 & -.07 & $-.14^{*}$ & $.22^{*}$ & $.27 *$ & 1 & & & & & & \\
\hline
\end{tabular}




\begin{tabular}{|c|c|c|c|c|c|c|c|c|c|c|c|c|}
\hline $\begin{array}{l}\text { Pç } \\
\text { aceleci }\end{array}$ & -.00 & .03 & $-.14 *$ & .11 & -.04 & .07 & 1 & & & & & \\
\hline $\begin{array}{l}\mathrm{PC} \\
\text { düşünen }\end{array}$ & $-.24 *$ & -.04 & .00 & -.08 & $\begin{array}{c}- \\
.21 *\end{array}$ & -.08 & -.06 & 1 & & & & \\
\hline $\begin{array}{l}\text { Pç } \\
\text { kaçıngan }\end{array}$ & .01 & -.06 & -.11 & .03 & .04 & $.18^{*}$ & $.45 *$ & $.13^{*}$ & 1 & & & \\
\hline Pç değ. & $-.16 *$ & -.03 & .04 & -.06 & -.09 & -0.7 & $.17^{*}$ & $.60 *$ & $.12 *$ & 1 & & \\
\hline $\begin{array}{l}\text { Pç } \\
\text { kendine } \\
\text { güvenli }\end{array}$ & $-.13^{*}$ & .03 & $-.13^{*}$ & -.10 & $\begin{array}{c}- \\
.21^{*}\end{array}$ & $\begin{array}{c}- \\
.14^{*}\end{array}$ & $.17^{*}$ & $.70^{*}$ & $.19 *$ & $.51 *$ & 1 & \\
\hline Pç planlı & $-.17 *$ & -.00 & .00 & $-.17^{*}$ & $\begin{array}{c}- \\
.31 *\end{array}$ & $\begin{array}{c}- \\
.17^{*}\end{array}$ & .11 & $.68^{*}$ & .07 & $.56^{*}$ & $.70^{*}$ & 1 \\
\hline
\end{tabular}

Danışanların problem çözme tarzlarının ve çok boyutlu algıladıkları sosyal destek düzeylerinin psikolojik danışma oturumları sonunda algıladıkları yaşantı ve davranış değişimi düzeyini yordama derecesini incelemek için gerçekleştirilen çoklu doğrusal hiyerarşik regresyon analizi sonucu Tablo 3 ve Tablo 4'te verilmiştir.

Tablo 3.

Danışanların problem çözme tarzları ve çok boyutlu algıladıkları sosyal destek düzeylerinin yaşantı ve davranışlarda değişim puanlarını yordama derecesine ilişkin $R$ ve $R^{2}$ değerleri

\begin{tabular}{lrrrrrrr}
\hline Değişken & $\boldsymbol{R}$ & $\boldsymbol{R}^{2}$ & $\boldsymbol{R}^{2}$ Değişim & $\boldsymbol{F}$ Değişim & $\boldsymbol{s} \boldsymbol{d 1}$ & $\boldsymbol{s} \boldsymbol{d} \mathbf{2}$ & Anlamlılık \\
\hline Oturum Sayısı & .10 & .01 & .005 & 2.10 & 1 & 198 & .149 \\
PÇ_DÜŞŠNEN & 0.254 & .07 & .06 & 11.38 & 1 & 197 & .001 \\
\hline PÇ; Problem Çözme & & & & & & &
\end{tabular}

Tablo 4.

Danışanların problem çözme tarzlarının ve çok boyutlu algıladıkları sosyal destek düzeylerinin danışanların algıladıkları yaşantı ve davranış değişim düzeylerini yordama derecesine ilişkin $B$, Beta değerleri ve anlamlılık düzeyi

\begin{tabular}{lrrrrr}
\hline Değişken & $\boldsymbol{B}$ & Std Hata & $\boldsymbol{B}$ & $\boldsymbol{T}$ & $\boldsymbol{P}$ \\
\hline (Sabit) & 233.70 & 6.63 & & 35.25 & .000 \\
Oturum Sayısı & 1.57 & 1.08 & .10 & 1.45 & .149 \\
\hline & & & & & \\
\hline (Sabit) & 253.16 & 8.66 & & 29.23 & .000 \\
Oturum Sayısı & 1.42 & 1.06 & .09 & 1.34 & .18 \\
PÇ DÜşÜNEN & -1.41 & .42 & -.23 & -3.37 & .001 \\
\hline
\end{tabular}

PÇ; Problem Çözme

Danışanların problem çözme tarzları ve çok boyutlu algıladıkları sosyal destek düzeylerinin, danışanların algıladıkları yaşantı ve davranış değişimi düzeylerini yordama derecesini incelemek için gerçekleştirilen çoklu doğrusal hiyerarşik regresyon analizinde, danışanların katılmış oldukları oturum sayısının etkisi birinci düzeyde analize sokularak sabit tutulmuştur. Danışanların problem çözme tarzları (aceleci, kaçıngan, değerlendirici, düşünen, kendine güvenen, planlı) ve çok boyutlu algıladıkları sosyal destek (aile, arkadaş, diğer kişi) düzeylerinin yaşantı ve davranış değişim düzeyini ne derece yordadığını belirlemek için aşamalı çoklu regresyon yöntemi ile regresyon analizine devam edilmiştir. Tablo 2 ve 3 incelendiğinde regresyon analizinin iki aşamada tamamlandığı görülmüştür. Tablo 2 ve Tablo 3'te de 
görüldüğü gibi danışanların katılmış oldukları oturum sayısının yaşantı ve davranışlardaki değişimin anlamlı bir yordayıcısı olmadığı, ayrıca aceleci problem çözme, kaçıngan problem çözme, değerlendirici problem çözme, kendine güvenli problem çözme, planlı problem çözme tarzı puanlarının, yaşantı ve davranışlarda değişim düzeyi puanlarını yordamada istatistiksel olarak anlamsız bulunmuştur. Danışanların cinsiyeti psikolojik danışma sürecinde algıladıkları yaşantı ve davranış değişim düzeyini yordamada anlamsız bulunmuştur. Bir başka deyişle danışanların algıladıkları yaşantı ve davranış değişimi düzeyinde erkek ya da kadın danışan olmanın bir değişim yaratmadığı söylenebilir.

Danışanların düşünen tarz problem çözme becerilerinin, danışanların algıladıkları yaşantı ve davranış değişimi düzeyi puanlarının anlamlı bir yordayıcısı olduğu görülmüştür.

Çoklu doğrusal hiyerarşik regresyon analizine sabit değişken olarak giren danışanların katılımıs oldukları oturum sayısının, yaşantı ve davranışlarda değişim düzeyi puanlarını yordama derecesi anlamlı bulunmamıştır $\left[R=.10, R^{2}=.01, F(1,198)=2.1, p>.05\right]$.

Regresyon analizinin ikinci aşamasında, düşünen tarz problem çözme puanlarının, yaşantı ve davranışlarda değişim düzeyini anlamlı şekilde yordadığı görülmüştür. $\left[R=.25, R^{2}=.05, F(1,197)=\right.$ $11.39, \mathrm{p}<.001]$. Düşünen tarz problem çözme puanları tek başına toplam varyansın $\% 5^{\prime}$ ini açıklamıştır. Bu açıklama düzeyi düşük düzeyde bir açıklama oranı olarak nitelendirilmektedir (Leech, Baret \& Morgan, 2008). Tablo 3'e bakıldığında, düşünen tarz problem çözme puanlarının, danışanların algıladığı yaşantı ve davranış değişim puanlarını yordamasına iliş̧in Beta değerinin ise negatif olduğu bulunmuştur. Bu durum düşünen tarz problem çözme puanları ile YADA puanlarının negatif korelasyon gösterdiğine işaret etmektedir.

\section{Tartışma, Sonuç ve Öneriler}

Bu araştırmada danışanların psikolojik danışma süreci sonunda algıladıkları yaşantı ve davranış değişimi düzeyinin, danışanların cinsiyet, katılmış oldukları oturum sayısı, algıladıkları sosyal destek ve problem çözme tarzına göre farklılaşıp farklılaşmadığı incelenmiştir.

Bu araştırmada, danışanların katılmış oldukları oturum sayısı, psikolojik danışma sürecinde algıladıkları yaşantı ve davranış değişim düzeyini yordamada anlamsız bulunmuştur. Bu araştırma kapsamında danışanların katılmış oldukları oturum sayısı en az 4, en çok 13 , ortalama oturum sayısı ise 5.85 olarak hesaplanmıştır. İlgili literatür incelendiğinde Clement (2008) çalışmasında danışanların katılmış olduğu ortalama oturum sayısı 17.43 olarak hesaplanmış ve oturum sayısı ile psikoterapi sonucu arasında anlamlı ve olumlu yönde bir ilişki bulunmuştur. Literatürde psikolojik danışma yardımının etkililiğinin oturum etkisini araştırma yolu ile ölçüldüğü görülmektedir (Kadera, Lambert ve Andrews, 1996; Anderson ve Lambert, 2001; Wolgast ve diğ., 2003). Bu çalışmalar incelendiğinde Kadera vd. (1996) danışanların anlamlı değişimi için 14 oturuma, Anderson ve Lambert (2001) 11 oturuma, Wolgast vd. (2003) 16 oturuma, ihtiyaç duyulduğunu ortaya koymuştur. Smith vd. (1980) danışanların katılmış oldukları oturum sayısı ile psikoterapi sonuçları arasında anlamlı bir ilişki ortaya koyamamıştır.

Illgili araştırmalar ile karşılaştırıldığında bu araştırmada danışanların katılmış oldukları oturum sayısının, literatürdeki oturum sayılarına göre nispeten az olduğu görülmektedir. Bu açıdan az sayıda oturum sayısına ulaşıldığı düşünüldüğünde değişimin gözlenmemiş olması beklendik bir sonuç olarak görülebilir. Bu araştırmada psikolojik danışma oturumlarının bir akademik dönem içinde planlanıp tamamlanması beklenmiştir. Psikolojik danışman adayları hali hazırda lisans öğrencisi oldukları için oturumların planlanması, yapılandırılması ve gerçekleştirilmesini ders, sınav ve çalışma programları doğrultusunda planlamak durumundadır. Danışan profili üniversite öğrencilerinden oluştuğu için planlama şartları (ders, sınav ve çalışma programları) psikolojik danışman adayları ile benzerlik göstermektedir. Bu durum göz önünde bulundurulduğunda ortalama 5.85 oturum sayısı uygun olarak 
görülebilir. Bu araştırma sonucu gerçekleştirilen ortalama oturum sayısının (5.85) danışanlarda yaşantı ve davranış değişimi gerçekleştirmek için yeterli olmayabileceğini ortaya koymaktadır. Bu sonuca dayanarak, psikolojik danışman adaylarına daha çok sayıda oturum gerçekleştirmeleri için koşulları ayarlamak ya da daha az sayıda oturumla daha etkili sonuçlar elde edecek yaklaşımların öğretilmesi etkili olabilir.

Bu araştırmada, danışanların cinsiyeti psikolojik danışma sürecinde algıladıkları yaşantı ve davranış değişim düzeyini yordamada anlamsız bulunmuştur. Bir başka deyişle danışanların algıladıkları yaşantı ve davranış değişimi düzeyinde erkek ya da kadın danışan olmanın bir değişim yaratmadığı söylenebilir. Clement (2008) çalışmasında da erkekler ve kadınlar çiftler ile karşılaştırıldığında anlamlı ölçüde ilerleme görülürken, iki cinsiyet arasında anlamlı bir fark bulunamamıştır. Ancak Clement (2008) çalışmasında cinsiyetler arasında anlamlı bir fark bulunamasa da sonuç ölçümlerinde kadınların puanlarının erkeklerin puanlarından daha yüksek olduğu belirtilmiştir. Sanberk (2010) çalışmasında danışanların cinsiyetini, psikolojik danışma sürecinde algıladıkları yaşantı ve davranış değişim düzeyini yordamada anlamsız olduğunu ortaya koymuştur.

Cinsiyete göre psikolojik danışma yardımından sağlanan fayda konusunda yapılan çalışmalar oldukça azdır (Ogrodniczuk, 2006). Var olan çalışmalar incelendiğinde ise tutarsız bulgular ile karşılaşılmaktadır. Smith, Glass ve Miller (1980) kadınlar ve erkeklerin psikoterapi sonuçlarında kadınların erkeklerden daha çok ilerleme kaydettiğini belirtmiştir. Ogrodniczuk vd. (2001) çalışmasında kadın ve erkeklerin farklı psikoterapi türlerinden daha fazla yararlanabileceği hipotezi ile yola çıkmış ve erkeklerin yorumlayııı terapide, kadınların ise destekleyici terapide daha iyi sonuçlar elde ettiğini ortaya koymuştur.

Çalışmaların küçük örneklemler ile yürütülmesi ve bu örneklemlerin çoğunlukla tek cinsiyeti genellikle kadınları- temsil ediyor olması, erkeklerin ve kadınların bulunduğu örneklemlerde ise kadın danışanların sayısının erkek danışanlara oranla oldukça fazla olması gibi yöntemsel zayıflıklar araştırma bulgularının tutarsız olmasına neden olabilir (Ogrodniczuk, 2006). Cinsiyetin psikoterapi sürecinde basit bir biyolojik değişken olarak ele alınması, cinsiyet rolleri, cinsiyet rol tutumları ve cinsel rol kimliklerinin göz ardı edilmesi de bulguları etkileyebilir. Cinsiyetin etkilerinin daha detaylı incelenmesi için daha kapsamlı araştırma modellerine intiyaç duyulmaktadır. Bu sonuçlarla birlikte değerlendirildiğinde bu çalışmada cinsiyetin yordayıcı çıkmaması ile örtüşen bulgular olduğu gibi (Clement, 2008; Ogrodniczuk, 2006; Sanberk, 2010) bu bulgu örneklemin küçüklüğünden ve araştırmadaki ortalama oturum sayısının sınırlı olmasından kaynaklanabilir.

Bu araştırmada danışanların aceleci problem çözme, kaçıngan problem çözme, değerlendirici problem çözme, kendine güvenli problem çözme, planlı problem çözme tarzı puanları, yaşantı ve davranışlarda değişim düzeyi puanlarını yordamada istatistiksel olarak anlamsız bulunmuştur.

Danışanların düşünen tarz problem çözme tarzının, danışanların algıladıkları yaşantı ve davranış değişimi düzeyi puanlarının negatif yönde anlamlı bir yordayıcısı olduğu görülmüştür. İlgili literatür incelendiğinde psikolojik danışma sürecinde danışanların problem çözme becerisinin ele alındığı çalışmalar yok denilecek kadar azdır. Problem çözme becerisi konusunda araştırmaların odağı problem çözme becerisi ve ruh sağlığı arasındaki ilişkidir. Literatürdeki araştırma bulguları incelendiğinde kişilerin problem çözme becerisi algısının umutsuzluk düzeyi, kısa ya da uzun süreli depresyon ve dolayısıyla intihar düşüncelerini yordamada anlamlı olduğu görülmektedir (Çam, 1997; Oğuztürk, Akça ve Şahin, 2011; Sardoğan vd., 2006; Taylan, 1990).

İlgili ölçek maddeleri göz önüne alındığında düşünen tarz problem çözmede kişi karşılaştığı durumla ilgili her türlü bilgiyi toplar ve gözden geçirir. Elde edilen tüm bilgiler problem çözme sürecinde dikkate alınır. Çözüm planını uygulamaya koymadan önce muhtemel sonuçlar üzerinde tahminler yürütülür, ne tür sonuçlar elde edilebileceğine dair değerlendirmeler yapılır. Karar verme aşamasına 
gelindiğinde ise her seçeneğin sonuçları ölçüp tartılır, birbirleriyle karşılaştırılır ve nihai karar verilir. Karar verme süreci tamamlandığında sonuç genellikle kişinin tahmin ettiği sonuç ile uyumludur. Bu araştırmada, düşünen tarz problem çözme becerisine sahip danışanların, psikolojik danışma süreci sonunda yaşantı ve davranış değişimini olumsuz yönde göstermiş oldukları saptanmıştır.

Heppner, Reeder ve Larson (1983) çalışmasında etkili ve etkisiz problem çözücülerin bilişsel süreçler bakımından birbirlerinden farklı olduklarını ortaya koymuştur. Etkili problem çözücülerin problem durumu üzerinde düşünmeyi sevdiklerini ve bu iş için zaman ayırdıklarını, var olan durumu kendi yaşantıları yolu ile anlama ihtiyacında olduklarını, diğer grubun ise problem durumlarında problem daha az odaklandıklarını, problem ile ilgili düşünmek yerine, kendilerini suçlama eğiliminde olduğunu belirtmiştir (Akt. Taylan, 1990). Başka bir deyişle problem durumu üzerinde düşünen ve problem çözmek için çaba sarfedenler, daha etkili şekilde problemlerini çözebilmektedir. Benzer olarak problem çözme sürecini aşamalı olarak ele alan (D'Zurilla ve Goldfried, 1971) ve problem çözme sürecinde ilgili tüm bilgilerin toplanmasına vurgu yapan (Heppner, 1978) çalışmalar mevcuttur (akt. Taylan, 1990). Bu bulgular doğrultusunda düşünen tarz problem çözme becerilerine sahip olan danışanların psikolojik danışma sürecinde daha avantajlı olmaları beklenebilir. Ancak bu araştırma psikolojik danışman adayları ile yürütülmüştür ve ortalama oturum sayısı 5.85 olarak hesaplanmıştır. Bu koşullarda beklenen değişimin gerçekleşmemiş olduğu ve bu aşamada düşünen tarz problem çözme tarzının daha çok problem üzerinde düşünme aşamasında takıldığı ve bu nedenle de değişim yönünde ilerlemediği düşünülebilir. Düşünen problem çözme tarzı gereği danışanların öncelikle problemlerine ve boyutlarına yoğun şekilde odaklanmalarının stres düzeylerini artırabileceği söylenebilir. Ölçümlerin böyle bir aşamada alınmış olmasının bu tarz ile değişim arasındaki negatif bulunan ilişkiyi açıklayabileceği düşünülebilir.

Bu araştırmada, danışanların algıladıkları sosyal destek düzeyi psikolojik danışma sürecinde algıladıkları yaşantı ve davranış değişim düzeyini yordamada istatistiksel olarak anlamsız bulunmuştur. Algılanan sosyal destek düzeyi, aile, arkadaş ve diğer önemli kişi alt ölçeklerinde danışanların algıladığı yaşantı ve davranış değişimi düzeyinde anlamlı farklılıklar görülmemiştir.

Sosyal destek değişkenine dair ilgili literatür incelendiğinde yerli ve yabancı literatürde sosyal desteğin iyilik hali, psikolojik dayanıklılık, psikolojik rahatsızlık düzeyi ile ilişkisinin ele alındığı görülmektedir. Psikolojik danışma sürecinde danışanların sosyal destek düzeylerini bağımsız değişken olarak ele alan çalışmaların sayısı oldukça azdır. Bu araştırmanın bulgularına benzer olarak, psikiyatrik semptom düzeyi ile sosyal destek düzeyi, niceliksel ve niteliksek sosyal destek değişkenlerinin ve algılanan sosyal desteğin depresyon ve anksiyete bozukluğu olan danışanlarda psikolojik rahatsızlıklar arasında anlamlı bir ilişki bulunamamıstır (Eurelings-Bonrekoe vd., 1996; Marzıali, 1987, Akt. Lindfors, Ojanen, Jääskeläinen ve Knekt, (2014). Benzer şekilde Roehrl ve Strouse (2008) çalışmasında psikolojik danışma sonuçları ile sosyal destek arasında .13 korelasyon bulmuştur. Bu bulgu ise düşük düzeyde bir ilişkiyi ifade etmektedir.

$\mathrm{Bu}$ araştırma, psikolojik danışma sonuçlarını danışan değişkenleri açısından değerlendirmektedir. Bu değişkenlerden biri olan algılanan sosyal destek düzeyini psikolojik danışma sürecinde ele alan araştırma sayısı yok denecek kadar azdır. Yerli literatürde iş̧legen (2011) çalışmasında danışanların algıladıkları sosyal destek düzeyinin terapötik çalışma uyumunu yordama gücünü incelemiştir. Algılanan sosyal desteğin terapötik çalışma uyumunun \%3"ünü açıklama gücüne sahip olduğu bulunmuştur. Araştırma bulgularında terapötik çalışma uyumu ile sosyal destek arasında düşük düzeyde anlamlı bir ilişki ortaya konmuştur.

Yine bu çalışmada sosyal desteğin yordayıcı çıkmaması az sayıdaki benzer bulgularla (EurelingsBonrekoe vd. 1996; Marzıali, 1987, Akt. Lindfors vd., 2014; Leibert, Smith ve Agaskar, 2011) tutarlı olmasına rağmen sosyal destek ve ruh sağlığı arasındaki bulgularla da örtüşmemektedir. Bu açıdan baktığımızda bu bulguya dikkatle yaklaşmalı ve psikolojik yardım alan üniversite öğrencileri ve bu 
süreçte sosyal desteklerinin rolü üzerinde yapılacak sonraki araştırmalardan elde edilecek bulgularla birlikte yorumlanmalıdır. Danışan profilinin üniversite öğrencilerinden oluştuğu düşünüldüğünde, ilgili literatürde üniversite öğrencilerinin üniversite hayatı ve beraberinde getirdiği zorluklar ile baş etme konusunda yetersiz sosyal destek algısı ile birlikte psikolojik danışma sürecine girdikleri vurgu yapılan bir konudur. Düşük düzeyde sosyal destek algısının psikolojik danışma yardımı alma tutumunu olumlu yönde etkilediği bulguları da mevcuttur (CepedaBenito ve Short, 1998; Karalp, 2009, Akt. Akeren ve Ay, 2019; Miville ve Constantine, 2006; Tata ve Leong, 1994). Bu nedenle yapılacak araştırmalarda danışanların psikolojik danışma sürecinin başında sahip oldukları sosyal destek algıları dikkate alınması gereken faktörlerden biri olarak değerlendirilebilir.

İlgili literatürde üniversite öğrencileri ile yürütülen çalışmalar incelendiğinde iyilik hali, psikolojik dayanıklılık, sosyal ve psikolojik iyi oluş, temel psikolojik ihtiyaçların doyumu gibi konular ile sosyal desteğin ilişkisi incelenmiştir ve anlamlı ilişki ortaya konmuştur. Bazı çalışmalarda ise tanı almış popülasyonlarla yürütülen psikolojik yardım süreçlerinde sosyal desteğin anlamlı bir yordayıcı olduğu bulgusu göze çarpmaktadır (Doğan, 2008; Surette ve Shier, 2017). Ancak söz konusu bu çalışmada katılımcılar psikolojik yardım alan üniversite öğrencileridir ve kliniğe başvurmuş ve nispeten tanı alma potansiyeli olan bir popülasyondan gelmedikleri düşünüldüğünde bu araştırmanın bulgularını yorumlamak için benzer katılımcı profilleri üzerinde çalışmış araştırmalara ihtiyaç vardır.

Araştırma kapsamında psikolojik danışma süreçlerinin psikolojik danışman adayları tarafından yürütülmüş olması ve psikolojik danışman adaylarının yürüttükleri psikolojik danışma süreçlerine ilişkin bulguların azlığı göz önüne alındığında da bu bulguyu yorumlamak yeni araştırmalara ihtiyaç olduğuna işaret etmektedir.

Mevcut araştırma bazı sınırlııılar içermektedir. Çalışmada incelenen psikolojik danışma oturumlarının hangi kurama ya da terapötik yönelime göre yapılandırıldığına dair bir bilgi bulunmamaktadır. Dolayısı ile psikolojik danışman adaylarının yansıttığı kuramsal bakış açısından sonuçların etkilenip etkilenmediği konusunda bir açıklama yapılamaz. Ayrıca incelenen psikolojik danışma oturumlarının benzer koşullar altında yürütülüp yürütülmediği konusunda da ders içerikleri dışında bir bilgi yoktur, olası farklııkların bulgulara yansımış olabileceği göz önünde bulundurulmalıdır. Son olarak, danışanların psikolojik danışma sürecine başvurma nedenleri-problem alanlarııın benzerlikleri ve farklılıklarının da sonuçlarla ilişkili olabileceği ancak kontrol edilemediği de dikkate alınmalıdır. Araştırmadan elde edilen bulgular, Yaşantı ve Davranışlarda Değişim ölçeği (YADA), Çok Boyutlu Algılanan Sosyal Destek Ölçeği (ÇBASDÖ) ve Problem Çözme Envanteri'nin (PÇE) ölçtüğü niteliklerle sınırlıdır. Psikolojik danışma süreçlerinin sonuçları aday psikolojik danışmanların psikolojik yardım sunduğu danışanlardan elde edildiği için deneyimli psikolojik danışmanların yürüttüğü psikolojik danışma süreçlerine genellenemez.

Bu araştırmadan elde edilen bulgular ışığında yapılacak araştırmalara ilişkin bazı öneriler geliştirilmiştir:

$\mathrm{Bu}$ araştırmada lisans düzeyinde psikolojik danışman adaylarının yardım sunduğu danışanlardan veri toplanmıştır. 200 danışan ile yürütülen bir çalışmadır. Lisans ve lisansüstü eğitimini tamamlamış ya da farklı deneyim düzeylerine sahip psikolojik danışmanların danışanlarından oluşan daha geniş örneklemler ile yapılacak çalışmalara ihtiyaç vardır. Gelecek yıllarda üniversite bünyelerinde bulunan Psikolojik Danışma ve Rehberlik birimlerine başvuran danışanlar ile yürütülen psikolojik danışma oturumlarından veri sağlanarak yapılan araştırmalar psikolojik danışma süreci sonuçlarına dair daha kapsamlı bilgiler sunabilir. Psikolojik yardım sürecinde, danışana dair değişkenler ile psikolojik danışman değişkenlerinin de dahil edilmesi ve çok yönlü bir değerlendirme yapılması daha tutarlı bulgular elde edilmesini sağlayabilir.

Bu araştırmada psikolojik danışma sürecinin sonuçları yardım süreci bitiminde uygulanan 
ölçekler aracılığıyla değerlendirilmiştir. Etkililik çalışmaları bizlere psikoterapi sonuçları hakkında oldukça fazla bilgi vermektedir. Fakat istatistiksel ölçümlere yapılan vurgu yaşanan deneyim ve anlam gibi sonucun önemli yönlerini inmal etmektedir. Deneysel çalışmalar, terapi sonrası ölçek uygulamaları ve diğer nicel yöntemler, psikoterapide neyin işe yaradığına dair kıymetli ancak sınırlı bilgiler sunmaktadır. Deneysel çalışmalara terapötik sonuçlara ilişkin danışan ve psikolojik danışman deneyimlerini içeren nitel boyutların da dahil edilerek karma yöntem ile yapılmasının yararlı olacağı düşünülmektedir. Özellikle yerli literatürde psikolojik danışma yardımının etkililiği, psikolojik danışma sürecinin sonuçları ya da psikolojik danışma sürecinde danışana ait değişkenler ile ilgili yürütülen çalışmalar yok denecek kadar azdır. İlgili literatüre katkı sağlamak adına bu konuda çalışmaların arttırılması önemlidir. 


\section{Kaynakça}

Aladağ, M. ve Bektaş, D. Y. (2007, Ekim). Psikolojik danışma eğitiminde psikolojik danışma becerilerinin kazandırılması. IX. Ulusal Psikolojik Danışma ve Rehberlik Kongresi'nde sözel bildiri olarak sunuldu, Dokuz Eylül Üniversitesi, İzmir, Türkiye.

Aladağ, M. ve Bektaş, D. Y. (2009). Examining individual-counseling practicum in a Turkish undergraduate counseling program. Eurasian Journal of Educational Research, 37, 53-70.

Akeren, í. ve Ay, í. (2019). Üniversite öğrencilerinde algılanan sosyal destek ve güvengenlik ile psikolojik yardım gereksinimlerinin incelenmesi. Uluslararası Türkçe Edebiyat Kültür Eğitim Dergisi, 8(2), 1222-1248.

Anderson, E. M. ve Lambert, M. J. (2001). A survival analysis of clinically significant change in outpatient psychotherapy. Journal of Clinical Psychotherapy, 57(7), 875-888.

Clarkin, J. F. ve Levy, K. N. (2004). The influence of client variables on psychotherapy. (5. bs.). M. J. Lambert (Ed.), Handbook of psychotherapy and behavior change (s. 194-226) içinde. New York: Wiley.

Clement, P. W. (2008). Outcomes from 40 years of psychotherapy in a private practice. American Journal of Psychotherapy, 62(3), 215-239.

Corey, G. (2008). Psikolojik danışma kuram ve uygulamaları (T. Ergene, Çev.) (1. bs.). Ankara: Mentis Yayıncılık.

Çakır, Y. ve Palabıyıkoğlu, R. (1997). Gençlerde sosyal destek- çok boyutlu algılanan sosyal destek ölçeğinin güvenirlik ve geçerlik çalışması. Kriz Dergisi, 5(1), 15-24.

Çam, S. (1997). Iletişim becerileri eğitimi programının öğretmen adaylarının ego durumlarına ve problem çözme becerisi algılarına etkisi. (Yayımlamamış doktora tezi), Ankara Üniversitesi, Ankara.

Denizli, S. (2010). Danışanların algıladıkları terapötik çalışma uyumu ve oturum etkisi düzeylerinin bazı değişkenlere göre yordanması: Ege Üniversitesi örneği. (Yayımlamamış doktora tezi), Ege Üniversitesi, İzmir.

Doğan, T. (2008). Psikolojik belirtilerin yordayıcısı olarak sosyal destek ve iyilik hali, Türk Psikolojik Danışma ve Rehberlik Dergisi, 3(30), 30-44.

Eker, D. ve Arkar, H. (1995a). Çok boyutlu algılanan sosyal destek ölçeğinin faktör yapısı, geçerlik ve güvenirliği. Türk Psikoloji Dergisi, 10, 45-55.

Eker, D., Arkar, H. ve Yaldız, H. (2001). Çok boyutlu algılanan sosyal destek ölçeğinin gözden geçirilmiş formunun faktör yapısı, geçerlik ve güvenirliği. Türk Psikiyatri Dergisi, 12(1), 17-25.

Gordon, R. (2012). Where oh where are the clients? The use of client factors in counselling psychology. Counselling Psychology Review, 27(4), 8-17.

Hackney, H., Cormier, S. (2008). Psikolojik danışma ilke ve teknikleri: Psikolojik yardım süreci el kitabı (T. Ergene, S. Aydemir Sevim, Çev.) (1. bs.). Ankara: Mentis Yayıncılık.

Heppner, P. P., Kivlighan, D. M. ve Wampold, B. E. (1999). Research design in counseling (2. bs.). Belmont: Wadsworth.

Hill, C. E., \& Lambert, M. J. (2004). Methodological issues in studying psychotherapy process and outcome. Lambert, M.J. (Ed.) (5. Bs.), Handbook of psychotherapy and behavior change (s.84-135) içinde. New York: Wiley.

İşlegen, G. (2011). Danışanların algıladıkları sosyal desteğin terapötik çalışma uyumunu yordama gücünün belirlenmesi. (Yayımlamamış yüksek lisans tezi), Ankara Üniversitesi, Ankara.

Kadera, S. W., Lambert, M. J., Andrews, A. A. (1996). How much therapy is really enough? A session by session analysis of the psychotherapy dose-effect relationship. The Journal of Psychotherapy Practice and Research, 5, 132-152.

Lambert, M. J., Bergin, A. E. ve Garfield, S. L. (2004). Introduction and historical overwiew. M. J. Lambert (Ed.) (5.bs.), Handbook of psychotherapy and behavior change (s.3-15) içinde. New York: Wiley.

Leech, N. L., Barrett, K. C., ve Morgan, G. A. (2008). SPSS for intermediate statics: Use and interpretation. (3. bs.). Mahwah, NJ, US: Lawrence Erlbaum Associates Publishers.

Leibert, T. W. (2006). Making change visible: The possibilities in assessing mental health counseling outcomes. Journal of Counseling \& Development, 84, 108-113.

Leibert, T. W., Smith J. B. ve Agaskar, V. R. (2011). Relationship between the working alliance and social support on counseling outcome. Journal of Clinical Psychology, 67(7), 709-719.

Lindfors, O., Ojanen, S., Jääskeläinen, T. ve Knekt, P. (2014). Social support as a predictor of the outcome of depressive and anxiety disorder in short-term and long-term psychotherapy. Psychiatry Research, 216, 44-51.

Meydan, B. (2010). Psikolojik danışman adaylarının içerik yansıtma ve duygu yansıtma becerilerine ilişkin yeterlik düzeylerinin incelenmesi. (Yayımlanmamış yüksek lisans tezi), Ege Üniversitesi, İzmir. 
Nugent, F. A. (1990). An introduction to the profession of counseling. Columbus, OH: Merrill Publishing Company.

Ogrodniczuk, J. S. (2006). Men, women and their outcome in psychotherapy. Psychotherapy Research, 16(4), 453-462.

Ogrodniczuk J. S., Piper, W. E., Joyce A. S.ve McCallum M. (2001). Effects of patient gender on outcome in two forms of short-term individual psychotherapy. The Journal of Psychotherapy Practice and Research, 10(2), 69-78.

Oguztürk, Ö., Akça, F. ve Şahin, G. (2011). Üniversite öğrencilerinde umutsuzluk düzeyi ile problem çözme becerileri arasındaki ilişkinin bazı değişkenler üzerinden incelenmesi. Klinik Psikiyatri, 14, 85-93.

Roehrle, B. ve Strouse, J. (2008). Influence of social support on success of therapeutic interventions: a metaanalytic review. Psychotherapy: Theory, Research, Practice, Training, 45(4), 464-476.

Sanberk, i. (2010). Psikolojik danışman-danışan ilişkisinin çözümlenmesi ve bazı süreç sonuç değişkenleri açısından incelenmesi. (Yayımlanmamış doktora tezi), Çukurova Üniversitesi, Adana.

Sardoğan, M. E., Karahan, T. F. ve Kaygusuz, C. (2006). Üniversite öğrencilerinin kullandıkları kararsızlık stratejilerinin problem çözme becerisi, cinsiyet, sınıf düzeyi ve fakülte türüne göre incelenmesi. Mersin Üniversitesi Eğitim Fakültesi Dergisi, 2(1), 78-97.

Sexton, T. (1993). A review of the counseling outcome research. G. R. Walzve, J. C. Bleuer (Ed.), Counselor efficiacy: assesing and using counseling outcomes research, a review of the counseling outcome research (s. 84-124) içinde. Washington, DC: Educational Research and Improvement (ED).

Smith M. L., Glass, G. V. ve Miller, T. I. (1980). Benefits of psychotherapy. The Johns Hopkins University Press.

Surette, T. E. ve Shier, M. L. (2017). A common factors approach to supporting university students experiencing psychological distress. Journal of College Student Psychotherapy, 31(2), 112-131.

Sürücü, M. ve Bacanlı, F. (2010). Üniversiteye uyumun psikolojik dayanıklılık ve demografik değişkenlere göre incelenmesi. GÜ Gazi Eğitim Fakültesi Dergisi, 30(2), 375-396.

Şahin, N., Şahin, N. H. ve Heppner P. P. (1993). Psychometric properties of the problem solving in a group of Turkish students. Cognitive Therapy and Research, 17(4), 379-396.

Taylan, S. (1990). Heppner'in problem çözme envanterinin uyarlama, geçerlik ve güvenirlik çalışmaları. (Yayınlanmamış yüksek lisans tezi), Ankara Üniversitesi, Ankara.

Topkaya, N. ve Meydan, B. (2013). Üniversite öğrencilerinin problem yaşadıkları alanlar, yardım kaynakları ve psikolojik yardım alma niyetleri. Trakya Üniversitesi Eğitim Fakültesi Dergisi, 3(1), 25-37.

Wolgast, B. M., Lambert, M. J. ve Puschner, B. (2003). The dose-response relationship at a college counseling center. Journal of College Student Psychotherapy, 18(2), 15-29.

Yaka, B. (2005). Psikolojik danışmanların temel psikolojik danışma becerilerine ilişkin yeterlik düzeylerinin bazı değişkenlere göre incelenmesi. (Yayınlanmamış yüksek lisans tezi), Ege Üniversitesi, İzmir. 